\title{
The Pointlessness of Pareto:
}

\section{Carrying Coase Further}

\author{
Guido Calabresi $\nmid$
}

Some fifty-five years ago, in a seminal article called The Nature of the Firm, a young socialist named Ronald Coase sought to explain the existence of firms, of organizations within which markets were replaced by hierarchy and command. ${ }^{1}$ Twenty-five years later, in The Problem of Social Cost, Ronald Coase, by then a middle-aged libertarian, indicated how markets could replace hierarchy and command structures to the perceived benefit of those who organized them. ${ }^{2}$ Five years ago, at a conference marking the fiftieth anniversary of The Nature of the Firm, Professor Coase described the insight which allowed him to explain the existence of firms in this way:.

The solution was to realize that there were costs of making transactions in a market economy and that it was necessary to incorporate them into

† Dean and Sterling Professor of Law, Yale Law School. This Article is the first of a series which I hope will ultimately become a book. An early version of parts of that book formed the Thomas $M$. Cooley Lectures which I delivered at the University of Michigan Law School on October 22-24, 1979, under the title Nonsense on Stilts?: The New Law and Economics Twenty Years Later. Other parts, including some revisions of the earlier lectures, were the basis of the Julius Rosenthal Lectures, entitled Beyond the New Economic Analysis of Law, which I gave at the Northwestern University Law School on November 4-7, 1984. The core of this Article was presented in lecture form at a conference celebrating the 50th anniversary of the publication of Ronald Coase's article, The Nature of the Firm. See infra note 1. Many of the other presentations made at that conference, including three lectures by Professor Coase, were published in 4 J.L. ECON. \& ORG. (1988).

I am grateful to my colleagues Bruce Ackerman, Jules Coleman, Robert Ellickson, Henry Hansmann, Jay Katz, Jerry Mashaw, Roberta Romano, Susan Rose-Ackerman, Peter Schuck, and Alan Schwartz, who read and commented on this Article. Any errors that remain are, of course, my own.

1. Coase, The Nature of the Firm, 4 ECONOMICA 386 (1937). In his comments at a conference commemorating the 50th anniversary of The Nature of the Firm, held at Yale University on May 14-16, 1987, under the auspices of the Economics of Organization program of the Yale University School of Organization and Management, Professor Coase mentioned that he was a socialist at the time he wrote the article. In the published version of his comments at the Yale conference, however, Coase mentions that, while he was a socialist when he first decided to study economics, his "basic approach" in The Nature of the Firm was given to him by the teachings of Amold Plant. Coase, The Nature of the Firm: Origin, 4 J.L. ECON. \& ORG. 3, 5, 7 (1988) [hereinafter Coase, Origin]. He then states that he never felt any need to reconcile his socialist sympathies with an acceptance of Plant's approach: "In my case my socialist views fell away fairly rapidly without any obvious stage of rejection." Id. at 8 . Thus, in his published version of the conference lecture, Coase suggests that he may no longer have been much of a socialist when he wrote The Nature of the Firm.

2. Coase, The Problem of Social Cost, 3 J.L. \& ECON. 1 (1960). 
the analysis. This was not done in economics at that time-nor, I may add, is it in most present-day economic theory. ${ }^{3}$

Perhaps because of Coase's socialism, The Nature of the Firm emphasized the costs of markets and pointed out that when nonmarket (i.e. command or hierarchical) structures could accomplish desired results at lower costs, people would organize themselves into such structures-for example, firms or even governments-in order better to achieve those results. Perhaps because Coase had become a libertarian, The Problem of Social Cost emphasized the possible benefits of markets. It pointed out that when transaction costs were not prohibitive, people would enter into transactions creating markets, not only to get around "inefficient" hierarchical or command structures, but also to fill the vacuum left by the absence of preexisting market or command relationships. As Professor Coase recognized, the underlying point is the same. ${ }^{4}$ Its importance for economic theory cannot be overstated, and indeed, has not yet been fully appreciated.

In this Article, I would like to take Coase's original insight, look out from it, and place it in a broader context than even he did some thirty years ago in The Problem of Social Cost. I wish to examine what happens to the whole notion of efficiency, and specifically to the concept of Pareto optimality, if we take seriously the insight that "there are costs of making transactions in a market economy."

My thesis can be summarized very simply. Transaction costs (including problems of rationality and knowledge), no less than existing technology, define what is currently achievable in any society-the Pareto frontier. It follows that any given society is always or will immediately arrive at a Pareto optimal point given transaction costs. Therefore no moves from the status quo are possible without either: (a) disadvantaging at least someone (hence making distributional considerations unavoidable); or (b) trying to shift the frontier outward (itself a chancy and costly process that usually entails distributional consequences). It also follows that the frequently made distinction between removing inefficiencies (making moves to the frontier) and innovating (pushing the frontier outward) is a false dichotomy. Once we recognize this, we can focus more clearly on developing a taxonomy of possible types of innovations, and so be in a better position to decide which are likely to be worth pursuing.

3. Coase, Origin, supra note 1, at 17. For a collection of some of Coase's leading essays, and some interesting new material as well, see R. COASE, THE FIRM, THE MARKET, AND THE LAW (1988).

4. In the published version of his lecture at the Yale conference mentioned above, supra note 1, Coase said that "the structure of the argument was similar" in both The Nature of the Firm and The Problem of Social Cost, but that "the problems that the concept of transaction costs was used to solve were quite different." Coase, The Nature of the Firm: Influence, 4 J.L. ECON. \& ORG. 33, 34 (1988). 


\section{THE SYMMETRY BETWEEN MARKETS AND COMMAND SYSTEMS}

Much has been said about why economists and lawyers did not accept The Nature of the Firm for a very long time, while they did accept The Problem of Social Cost within a few years of its publication..$^{5}$ Certainly The Nature of the Firm seemed to require of economists work that they, by and large, do not like to do. Studies of the comparative costs of market and nonmarket forms did not have the appeal of high theory for economists then, nor, as Coase has said, do they now. ${ }^{6}$ And such was the world some fifty-five years ago that lawyers, who might have seen in the article an appeal for precisely the type of comparative institutional analysis with which much of United States legal scholarship is concerned, did not read it.

Why, then, was The Problem of Social Cost so well received? Many economists mistook the article to be a justification for the primacy of markets and for the absence of any need for law or command. ${ }^{7}$ As such, it did not seem to require hard work in comparative institutions, but only more, and more elegant, tinkering with market processes. Moreover, this time lawyers did read the article. It was published in a journal readily available to them, and came out at the same time as other writings that, together with it, made economics a subject of prime interest to legal scholars. ${ }^{8}$ And while legal scholars also missed its full force and subtlety, ${ }^{9}$ they did soon see it as justifying their own comparative studies of when command systems (regulation or criminal law),

5. See id. at 34-35.

6. See supra text accompanying note 3.

7. See, e.g., Cheung, The Structure of a Contract and the Theory of a Non-Exclusive Resource, $13 \mathrm{~J} . \mathrm{L}$. \& ECON. 49, 66-70 \& n.54 (1970); Regan, The Problem of Social Cost Revisited, 15 J.L. \& ECON. 427, 437 (1972); Stigler, The Law and Economics of Public Policy: A Plea to the Scholars, 1 J. LEGAL STUD. 1, 11-12 (1972).

8. The Journal of Law and Economics had, because of its earlier focus on antitrust and related issues, a significant readership among legal scholars. See Kitch, The Fire of Truth: A Remembrance of Law and Economics at Chicago, 1932-1970, 26 J.L. \& ECON. 163, 191-93 (1983). Contemporaneously to, and independently of, the publication of Coase's The Problem of Social Cost, I published Some Thoughts on Risk Distribution and the Law of Torts, 70 YALE L.J. 499 (1961). Somewhat later, in Italy, Pietro Trimarchi published RISCHIO E RESPONSABIITA OGGETTIVA (1961). Mention should also be made of Becker's writings on criminal law. See, e.g., Becker, Crime and Punishment: An Economic Approach, 76 J. POL. ECON. 169 (1968). Professor (now Judge) Richard Posner, in his distinguished book, The Economic Analysis of Law, dates the birth of the new economic analysis of law to the publication of Coase's and my articles and details the reasons that it took hold so quickly. See R. POSNER, THE ECONOMIC ANALYSIS OF LAW 19-20 (3d ed. 1986). Elsewhere, he also notes some quirks regarding the actual appearance as against the publication dates of these early articles and their relationship to each other. See Posner, The Economic Approach to Law, 53 TEX. L. REV. 757, 759 n.9 (1975).

This is not, of course, to say that earlier work on the economic analysis of law did not exist. For a discussion of a particularly interesting example, see Englard, Victor Mataja's Liability for Damages from an Economic Viewpoint - A Centennial to an Ignored Economic Analyst of Tort, 10 INT'L REV. L. \& ECON. 173 (1990).

9. See Calabresi, The Decision for Accidents: An Approach to Nonfault Allocation of Costs, 78 HARV. L. REv. 713, 730-31 nn.28 \& 30 (1965); Calabresi, Fault, Accidents and the Wonderful World of Blum and Kalven, 75 YALE L.J. 216, 231-32 \& nn.27-30 (1965), corrected in Calabresi, Transaction Costs, Resource Allocation and Liability Rules-A Comment, 11 J.L. \& ECON. 67 (1968) [hereinafter Calabresi, Transaction Costs]. 
mixed approaches (tort or liability rules), or market regimes (free contract) worked best. ${ }^{10}$

Another and more important reason why lawyers and economists ignored The Nature of the Firm is the extraordinary breadth of its insight. A full understanding of the costs and possible benefits of markets requires us to accept something which runs against some of our most basic presuppositions. It requires us to realize that neither market nor nonmarket forms of organization are primary; rather, they are two approaches which interrelate in oddly symmetrical ways as (a) people seek to find the most efficient (least costly) way of structuring their relationships, and, given that both approaches exist, (b) people try to use the power (wealth or authority) which each approach gives them to accrue maximum benefits to themselves.

Obviously, both markets and command structures have distributional consequences. In a market regime, some are made richer and some made poorer; in a command structure, some have greater authority and some less. It is equally clear that, in an all-market regime, wealth constitutes authority, and that, in an all-command structure, authority results in wealth. Also true, but perhaps less plain, is the fact that in mixed systems like ours people will use their distributional advantage in one medium to overcome their distributional disadvantage in the other by "altering" or "corrupting" that other medium. The use of money to influence or "corrupt" those in authority is easy enough to understand, whether through bribes or campaign contributions. But so, if we are but to look, is the reverse. The proverbial cop on the beat, who takes an apple from a fruit stand and does not pay for it, uses authority to alter or "corrupt" the market. The cop is weak in funds, but strong in authority, and uses it to get cheaply what in money would be relatively more costly. Conversely, the briber is weak in authority but strong in wealth, and uses wealth to get what was to be allocated by command rather than markets. ${ }^{11}$ The symmetry is haunting.

Coase, in his great articles, focused on the symmetry between command and market systems where the object was the establishment of efficient ways of achieving mutually desired ends. I have, in the last paragraph, suggested that the same symmetry exists with respect to distributional issues. That will be my focus in subsequent articles, in which I shall examine the consequences of the

10. See, e.g., J. COLEMAN, Crimes, Kickers and Transaction Structures, in MARKETS, MORALS AND THE LAW 153, 157, 161-65 (1988); Calabresi, Torts-The Law of the Mixed Society, in AMERICAN LAW: THE THIRD CENTURY 103, 116 n.11 (B. Schwartz ed. 1976), reprinted in 56 TEX. L. REV. 519,525 n.11 (1978); Calabresi \& Melamed, Property Rules, Liability Rules, and Inalienability: One View of the Cathedral, 85 HARV. L. REV. 1089, 1094 n.12 (1972); Klevorick, On the Economic Theory of Crime, in CRIMINAL JUSTICE: NOMOS XXVII 289, 300-04 (J. Pennock \& J. Chapman eds. 1985); Michelman, Pollution as a Tort: A Non-Accidental Perspective on Calabresi's Costs (Book Review), 80 YALE L.J. 647, 649, 66686 (1971). See generally J. COLEMAN, The Morality of Strict Tort Liability, in MARKETS, MORALS AND THE LAW, supra, at 166 (reviewing various justifications for systems of liability rules).

11. See G. CALABResi \& P. BobBITT, TRAGIC ChoICES 122-24 (1978) (discussing role of corruption in various systems of allocation). 
symmetry between command and market approaches in more detail in a world in which Pareto optimality is no guide and distributional issues cannot, even in theory, be avoided. In this Article, I will concentrate on explaining why Pareto optimality cannot be a guide, and the consequences of that fact.

\section{What Is Is Optimal, UNTIL We Change IT}

You have heard it said that, if there are no transaction costs, any starting point will be, or will immediately and with unanimous consent lead to, an efficient end point. (That is the old law.) ${ }^{12}$ Some have taken this to be the central meaning of Coase's work. But, as The Nature of the Firm demonstrates, Coase is just as concerned with what to do given the existence of transaction costs. I say to you that if efficiency is defined in terms of a strict (or, as it is sometimes termed, fanatical) Pareto test, ${ }^{13}$ any starting point will be, or will immediately lead to, an efficient end point, even with transaction costs. (That is the new law!)

What is the Pareto test? It is a simple unanimity requirement. It says that a society is not at its optimal position if there exists at least one change which would make someone in that society better off and no one in it worse off. ${ }^{14}$

12. Coase, The Problem of Social Cost, supra note 2. Some confusion arose because Coase seemed to say that whatever the starting points, absent transaction costs, the same end point would be reached. See id. at 4-8; see also Calabresi, Transaction Costs, supra note 9, at 67. Any number of writers correctly pointed out that the same end point would not, in fact, be reached, because starting points determine wealth, wealth affects tastes, and these "income effects" would determine which end point would be reached. See, e.g., Regan, supra note 7, at 433. What Coase (and his followers) clearly meant, however, was that, absent transaction costs, an equally efficient point would be reached regardless of starting points. See, e.g., Calabresi \& Hirschoff, Toward a Test for Strict Liability in Torts, 81 YALE L.J. 1055, 1058 n.12 (1972). That is, in all cases a point would be reached which would be the same as far as efficiency was concerned. There are, of course, any number of "efficient" positions. Which position one reaches depends, among other things, on such things as underlying wealth and tastes. See, e.g., G. STIGLER, THE THEORY OF PRICE 33-41 (1966).

13. See, e.g., Dworkin, Why Efficiency?: A Response to Professors Calabresi and Posner, 8 HofsTRA L. REV. 563,582 (1980).

14. I use "better off" and "worse off" in the broadest possible sense. Thus I include not only material, emotional, and psychological well-being in these terms, but also what might be called preferences and judgments. If I prefer state one to state two because I believe your condition to be worse in state two, I am, as I use the words, worse off in state two, even if you do not share my view and even if in all other particulars state two might be more desirable for me. Similarly, if I would rather be in state one than in state two because I believe that those who are bettered by the move to state two do not deserve to be, then, in my terminology, I am worse off in state two than state one, whatever other advantages state two may have for me. $C$ f. infra note 36 (arguing that meeting distributional goals through generalized tax or welfare programs inadequate in part because judgments as to "wrongfulness" often best made in particularized decisions).

For a full definition of Pareto optimality and Pareto superior moves, see J. CoLEMAN, Efficiency, Auction and Exchange, in MARKETS, MORALS AND THE LAW, supra note 10, at 67, 72, which states: "An allocation of resources is Pareto superior to an alternative allocation if and only if no person is disadvantaged by it and the lot of at least one person is improved"; R. POSNER, supra note 8 , at 12 , in which a Pareto superior transaction is termed "one that makes at least one person in the world better off and no one worse off”; P. SAMUELSON \& W. NORDHAUS, ECONOMICS 966 (13th ed. 1989), in which Pareto efficiency is defined as "[a]n economic outcome in which no reorganization or trade could occur that would raise the utility or satisfaction of one individual without lowering the utility or satisfaction of another individual." The test derives from the writings of the great Italian economist, Vilfredo Pareto (1848-1923). It is by no 
So stated, it has enormous intuitive appeal. If it had any force, it would mean that, however bizarre or nefarious the original starting points and the tastes they defined, and however outrageous the wealth and power distributions that our law created or took for granted, nevertheless existing laws could be attacked if they were not Pareto optimal. As such, it would seem to be a normative guide which lawyers, economists, and lawyer-economists could follow to achieve a somewhat better society. Even if other changes that would hurt some and help others, and which might in some sense be even more important or desirable, were possible, no one could deny that the Pareto-indicated changes would themselves be worth pursuing. ${ }^{15}$ And that would be no small thing.

Unfortunately, the set of Pareto superior changes which would make no one worse off and at least one person better off must ex ante be a void set. For if strict or fanatical Pareto is the criterion, why wouldn't any change that belonged in the set have already been made? Since, by definition, no one would in any way be hurt by the change, why would anyone object? The existence of ex ante objectors itself must mean that there are some people who-rightly or wrongly-believe that they will lose something from the change. Putting it another way: if Pareto optimality means a place where no improvement can be made without ex ante creating the possibility that there will be some losers, then we are always there. And if the strict Pareto test is the appropriate definition of efficiency, then what is is efficient, though it may be only one of many such arrangements. ${ }^{16}$ Moreover, it will remain efficient at least until a new and better arrangement becomes known and achievable without hurting anyone. Once that happens, we will go there forthwith, without the need for a lot of expensive lawyer-economists to tell us to do it. Why would we ever fail to move to what is unanimously acceptable if we had the requisite knowledge and ability to do it? Why would we need anyone to tell us that we should do it? ${ }^{17}$

This does not, of course, mean that where we are is desirable. Nor does it mean that, as a result of political discourse, or economic or technological innovations, we could not find ourselves able to conclude unanimously that a change would be preferable. These are quite different issues, about which I will have much more to say soon enough. But it does mean that the Pareto criterion is of no general use as a normative guide.

It would be quite different if we were to use a less strict Pareto criterion. Were we to define Pareto superior moves as those which left no one worse off

means clear that Pareto himself believed that the test had practical value as a policy guide. C. POWERS, VILFREDO PARETO 143-44 (1987). The use of approaches, like Pareto optimality, that attempt to make economics scientific and value-neutral are more properly linked to the celebrated English economist, Lionel Robbins. See L. RobBINS, THE NATURE AND SIGNIFICANCE OF ECONOMIC SCIENCE (2d ed. 1935).

15. Thus Pareto-indicated changes would be what Dworkin has termed a "component of value." See Dworkin, supra note 13, at 563.

16. See supra note 12 .

17. There may of course be lags between knowledge by some that a better state exists and achievement of that state through unanimous agreement. For my purposes, such lags are simply another form of transaction costs. For a treatment of the significance of transaction costs, see infra Part III. 
financially and made some financially better off, then it would not follow that where we are is, ex ante, Pareto optimal. Some people might keep us from making such (pseudo) Pareto superior moves because, though such moves would leave them financially as well off, they would be morally or psychologically injured by the change. Similarly, a change that would make the rich richer and the poor no poorer might be blocked by those who decried the greater "maldistribution" of wealth. And a change that would make the poor better off, but would leave the rich as rich, might be successfully opposed by those who found any move toward greater egalitarianism hateful. Finally, envy might inspire some to object successfully to a change that helped others, though it left the objectors otherwise untouched. And still others might do the same because failing to object would mean giving up a bargaining chip, a claim on part of the gains that the change would make available. In all these cases, a change which many would deem an improvement will come about only if we can convince or compensate those who object to its taking place. If we must compel them in order to get there, however, then, no matter how desirable such a change may appear to some of us, it cannot be termed a Pareto superior move without gutting the Pareto concept of all its force..$^{18}$

In each of the cases described, someone loses. The rest of us may believe that the loser's loss ought not to matter because it is unworthy or unimportant compared to the winner's gain. And we may well be right. But the moment we are willing to say that, we have introduced a nonunanimously held value into the scheme, and it is then open season. As far as economic efficiency is concerned, we would then be engaged in interpersonal comparisons, and there is no reason based in economics or efficiency why some such comparisons should be allowed and others excluded. ${ }^{19}$ We would have entered into a fully normative world where the identity and merit of the winners and losers becomes of the essence.

Let me be clear. That normative world is the one in which we live, and we can say a good deal about what is better and what is worse in it. What we cannot do, though, is to hide what is involved in such a world behind an interpersonally neutral criterion and act as though we are not making moral judgments, the effects of which we then impose on others.

18. See Dworkin, supra note 13 , at 582 (although change makes most better off, if even one person made worse off then Pareto justification "destroyed").

19. See, e.g., J. COLEMAN, Efficiency, Utility and Wealth Maximization, in MARKETS, MORALS AND THE LAW, supra note 10 , at 95,102 ("This is not to say, of course, that there are no distributions that contain more total utility than a Pareto-optimal distribution. Rather, given the constraints of the theory, we cannot determine, short of making actual interpersonal comparisons, which distributions they are."). 


\section{The EFfect of Transaction Costs}

But what of transaction costs? Is it not the case that there might be a change which, if we could but make it, would improve everyone's lot, but which we cannot make unanimously because transaction costs preclude us from doing so? Did not Coase, read literally, say precisely this when he declared that, absent transaction costs, we would always reach an efficient point regardless of where we started out? ${ }^{20}$ Indeed, can we not refine that statement and say that it is not only the costs of entering into deals that keep us from bettering everyone's lot, but also a lack of knowledge that a change would in fact be an improvement for all, or a lack of capacity or willingness to compensate adequately those who would initially lose from the change, or, finally, a failed game in which the division of gains cannot be agreed upon and hence no change is made? ${ }^{21}$ Coase would, of course, term all of these barriers transaction costs. In addition, it is surely possible that if someone compelled us to make some moves, we might all agree in retrospect that no one was left worse off. There can be no doubt that failures of knowledge, organization, and compensation often keep us from what, if it could be done, would make us all better off. So, too, it must be admitted, does failure to use compulsion. Does not the Pareto criterion point to what is clearly desirable, if only we could find a way of eliminating, or perhaps even just reducing, these impediments?

The answer, unfortunately, is that it does not. Or better, those who would seek to use the Pareto criterion in this way fail to consider that there is no difference, in theory or in practice, between the reduction or elimination of these impediments and any other innovation in knowledge or organization which might make us all better off-an engine which wastes less energy through friction, for example. The essence of Coase's insight is that transaction costs are no different from any other costs. As such, to put the matter in technical language, they may at any given moment help define the Pareto possibility frontier, that series of social states that represent the best we can do at the moment without making someone worse off..$^{22}$ But so does the fact that we do not have an engine that runs with less friction or that manna does not

20. I do not mean here, or in the next several sections, to imply that where we start out initially is set only by law. Such "legal centralism," as it has been termed, is clearly incorrect. Because legal entitlements are costly to establish and to learn, people often create initial entitlements informally by honoring culturally developed norms. The interplay between cultural and legal entitlements is an area of great importance and increasing scholarly interest. See, e.g., Ellickson, The Case for Coase and Against "Coaseanism," 99 YALE L.J. 611, 627-29 (1989); Ellickson, A Critique of Economic and Sociological Theories of Social Control, 16 J. LEGAL STUD. 67, 81-90 (1986); Ellickson, Of Coase and Cattle: Dispute Resolution Among Neighbors in Shasta County, 38 STAN. L. REV. 623 (1986); and authorities cited therein.

21. For a description of such games, see E. RASMUSSEN, GAMES AND INFORMATION: AN INTRODUCTION TO GAME THEORY 22-25 (1989).

22. For a precise definition of the Pareto frontier, see J. Coleman, supra note 19, at 102 ("[A]ll Pareto-optimal allocations may be represented as points on a utility-possibility frontier . . . That is, all points on the utility-possibility frontier are Pareto improvements over all points to their southwest. With respect to every other point, a point on the frontier is Pareto noncomparable."). 
rain from heaven. Thus, the existence of transaction costs no more keeps us from reaching a frontier that is, in fact, currently available to us than does the fact that today a given degree of friction is a reality of life and that manna does not at the moment rain from heaven. All of these do the same thing. They define what is and what is not currently feasible.

It may well be that tomorrow transaction costs will be lower, that our knowledge or organization will be better, that our envy will be less, that superconductors will reduce friction, and that it will rain manna. It may then be possible to help some and hurt no one. But each of these cases represents a moving outward of the frontier, not the removal of an inefficiency which heretofore had kept us from reaching the preexisting frontier. Once we understand the full significance of Coase's statement that transaction costs are costs, once we understand that their economic effect is the same as that stemming from the existence of friction, from the absence of manna, and from our incapacity to reduce the first or produce the second cheaply enough, then we must conclude that a move to the frontier and a shift of the frontier are, plain and simply, the same thing.

This does not by any means imply that all costs are the same, or that we should spend as much time, effort, or money trying to overcome each of them. Indeed, as we shall see soon enough, once liberated from the misperception that some predetermined abstract categories of costs are in some sense "unreal" or "mere inefficiencies," obviously to be overcome, while others, defined equally abstractly, can only be conquered by costly or risky processes like "innovations," we can get down to the real job of deciding which impediments to a better life (which barriers to movements of the frontier) seem to be most worth attacking and which, for the moment, appear not to be worth the effort. ${ }^{23}$

Still, some may say that $I$ have been too quick to assume the intractability of transaction costs and that collective interventions or legal changes that reduce impediments to transactions can often be achieved, thus leading to Pareto superior moves. Others will argue that I have been using the wrong definition of efficiency, that the Kaldor-Hicks test gives us the appropriate criterion. ${ }^{24}$ It is, they would add, the effect of transaction costs on that criterion that I should discuss. In fact, I believe that both of these points have already been implicitly countered in the foregoing discussion. But it may be well to consider them explicitly.

23. See infra text accompanying notes 61-78.

24. For a definition and discussion of the Kaldor-Hicks test, see infra Part V. 


\section{COLLECTIVE INTERVENTIONS AND REMOVING IMPEDIMENTS TO TRANSACTIONS}

It is no use to say that, when transaction costs keep us from achieving a state in which some are better off and none worse off, we should use "nonmarket methods" to reach that position. The statement seems plausible because the existence of high transaction costs suggests that we should replace expensive markets with cheaper, nonmarket forms of organization. But The Nature of the Firm provides the answer to this proposition. If we knew of and had available to us a nonmarket method that is ex ante Pareto superior, we would already have used it! That is precisely Coase's explanation of how firms come into existence. ${ }^{25}$ If we have not used such a market substitute, it must be because some people, rightly or wrongly, believe that they will lose from its establishment. That is, some oppose the move to the nonmarket structure because they believe they do better under a market structure. And those who would gain from the change cannot feasibly compensate them for their losses, either because it is too expensive to do so, or because agreements to compensate cannot be enforced.

The ideologically opposite approach to the existence of high transaction costs can be countered in exactly the same way. Some say that if transaction costs keep us from making Pareto superior moves, we should remove the impediments to transactions. We should, for example, implement legal changes that foster inexpensive negotiations and markets. Such changes, they argue, will lead to Pareto improvements. ${ }^{26}$ But once again the answer lies in the question: Who loses from the removal of impediments to transactions or from cheaper markets? If nobody believes they will lose, then we would have removed these impediments long since. If someone, rightly or wrongly, expects to lose, and compensation is not feasible, then the change will not be ex ante Pareto superior.

As I suggested before, game theoretic impediments to moves to nonmarket structures or to lower transaction cost structures which would themselves lead to allegedly Pareto superior changes, like game theoretic impediments to moves that lead directly to supposedly Pareto superior positions, are, in this sense, no different from other impediments. Society cannot achieve an otherwise Pareto superior position because someone is unwilling to lose a bargaining chip (which could be traded for a share of the gains), because the parties lack knowledge of the other's strategy, or, as in the prisoner's dilemma, because the organization needed to enforce silence on both parties is lacking and creation of the

25. See supra text accompanying note 4.

26. See, e.g., Demsetz, The Exchange and Enforcement of Property Rights, 7 J.L. \& ECON. 11, 20-26 (1964); Posner, Utilitarianism, Economics, and Legal Theory, 8 J. LEGAL STUD. 103, 135 (1979). 
requisite organization is either too expensive or harmful to someone else (in this case the jailer). ${ }^{27}$

My point in all this remains the same. I am not denying the possibility of discoveries, forced moves, or chance changes that, in retrospect, leave everyone better off. Nor am I saying that those who expect to lose may not become convinced (again, rightly or wrongly) that a move will, in fact, be to their advantage. Finally, I am certainly not denying that it may be worthwhile to pay people - economists, for example, or even lawyer-economists- to try to convince us all that a change would be universally desirable. (To say that would be precisely the same as making the foolish statement that it is never worthwhile to pay would-be inventors to try to discover things that would make life better for us all.) I am saying that one cannot criticize existing arrangements on the assumption that a universally better position is available to us. If it were, and we all knew of it, we would not need the criticism. If we do not all know of it, that very lack of knowledge is as much an impediment to improvement as is the lack of knowledge that keeps us from being better off before an invention or discovery dispels our ignorance. In each case it is misleading, and wrong, to act as though there were a Pareto superior move currently available. In each case, until our knowledge or organizational capacity increases, the improvement is no more than wishful thinking or a self-serving justification for scholarly work designed to give us the requisite knowledge.

\section{OF KALDOR-HICKS OR POTENTIAL Pareto SUPERToRITy}

Some may argue, however, that I have been using the wrong definition of efficiency. The appropriate definition, they would say, is that given by the Kaldor-Hicks test. This test roughly states that a move is efficient whenever the winners win more than the losers lose, in the sense that, if the winners compensated the losers to their satisfaction, the winners would still be better off than they were before the change. ${ }^{28}$ (This test is sometimes called potential Pareto superiority, because it has the potential of leading to a Pareto improvement. Achieving that potential, however, depends on successful compensation

27. Technically, these are not game theoretic impediments, but rather problems of collective action among rational agents which are described by various games that have certain forms or payoff structures.

The prisoner's dilemma was originally attributed to A.W. Tucker. For a simple description of the dilemma, see L. THOMAS, GAMES, THEORY AND APPLICATIONS 55-56 (1986). For a more complex application of the prisoner's dilemma to economic behavior, see Harsanyi, A General Theory of Rational Behavior in Game Situations, 34 ECONOMETRICA 613 (1966).

28. Lawyers and economists have used Kaldor-Hicks efficiency as either a utility-maximizing or wealthmaximizing requirement. In each case, unless, at a minimum, compensation of losers actually occurs, Kaldor-Hicks efficiency is subject to the Scitovsky Paradox-the idea that two opposite social states can be Kaldor-Hicks efficient with respect to one another. This is the result of different starting points shaping tastes differently, and hence also shaping what is efficient. See supra note 12. For a precise description of the Kaldor-Hicks test and the Scitovsky Paradox, see J. COLEMAN, supra note 19, at 98-100, 104-05. For a description by Posner of the applicability of Kaldor-Hicks to his legal theories, see R. POSNER, supra note 8, at 3-26. 
of losers, to their satisfaction. But actual compensation is not required by the Kaldor-Hicks test and may not even be feasible. ${ }^{29}$ )

Coase's statement that absent transaction costs any starting point will lead to an efficient end point is undoubtedly true if we apply a Kaldor-Hicks test for efficiency. Many have made use of Coase's insight with this result in mind, and have gone no further. ${ }^{30}$ To see why this cannot be a satisfactory conclusion to the inquiry, we must examine why it is that, absent transaction costs, any starting point will lead to Kaldor-Hicks efficiency. We will then be able to see why achieving that efficiency does nothing to alter the underlying problems and possibilities that the failure of the strict Pareto criterion has left us.

In the absence of transaction costs, in the Coasean sense of the term, compensation of losers is in every case achievable. Any move that would yield more to winners than it would cost losers will take place voluntarily because adequate knowledge and organization will always exist. Losers will, therefore, be able to demand the precise compensation that leaves them at least as well off as before, while winners will know that unless they pay that compensation they will have to forego their gain. Winners and losers will successfully resolve arguments over the division of the gains (i.e., of the surplus), for absence of transaction costs means that they will work out all games so as to create that division of the gains that will maximize the surplus. ${ }^{31}$

In other words, in the absence of transaction costs, society will achieve all Kaldor-Hicks superior moves voluntarily and unanimously and, under those circumstances, anything that is Kaldor-Hicks superior will also be Pareto superior! This is a simple truism. By the very definition of Kaldor-Hicks efficiency, the only thing that makes Kaldor-Hicks superior moves only potentially Pareto superior instead of truly Pareto superior is the absence of adequate compensation. And without transaction costs, winners can always give compensation. It follows that, absent transaction costs, society will achieve KaldorHicks efficiency by unanimous consent without anyone needing to fuss about it. $^{32}$

29. See G. CALABRESI \& P. BOBBITT, supra note 11, at 85-86; R. POSNER, supra note 8, at 13.

30. See, e.g., G. BECKER, Irrational Behavior and Economic Theory, in THE ECONOMTC APPROACH TO HUMAN BEHAVIOR 153, 167-68 (1976); R. POSNER, supra note 8, at 1-17, 23; Demsetz, supra note 26, at 26; Polinsky, Controlling Externalities and Protecting Entillements: Property Right, Liability Rule, and Tax-Subsidy Approaches, 8 J. LEGAL STUD. 1, 4-5 (1979); Posner, Law and Economics is Moral, 24 VAL. U.L. REV. 163, 166 (1990).

31. Thus, both maximization of total utility and compensation of all losers would occur. See Calabresi, Transaction Costs, supra note 9, at 68 .

32. Nicholas Kaldor himself, in explaining the Kaldor-Hicks test, stated: "This principle, as the reader will observe, simply amounts to saying that there is no interpersonal comparison of satisfactions involved in judging any policy designed to increase the sum total of wealth just because any such policy could be carried out in a way as to secure unanimous consent." Kaldor, Welfare Propositions of Economics and Interpersonal Comparisons of Utility, 49 ECON. J. 549, 551 n.1 (1939).

In the total absence of transaction costs such compensation would, of course, also encompass any thirdparty losers, including any who lost due to the opportunity costs of the move made. 
But, of course, there are transaction costs such that adequate compensation of losers to their satisfaction is by no means assured. Without intervention, then, we are very likely to be in positions which, though Pareto optimal, are not Kaldor-Hicks efficient. We will have available to us changes that will not occur voluntarily, and which could lead to winners winning more than losers lose.

Unless one is willing to make interpersonal comparisons, however, it simply cannot be said that such an uncompensated Kaldor-Hicks move is an improvement. ${ }^{33}$ In that crucial sense, Kaldor-Hicks superior moves fail to be neutral among people in the way that Pareto superior ones are.

There are, of course, ways of trying to get around this. In the end, however, they all fail. Either they assume some theory of just distribution, which, in the abstract, is no better than other possible distributional theories; or, in a vain attempt to convert compulsion into consent, they assume agreements that have never been made. Let me describe two such attempts made by one of today's most distinguished lawyer-economists, Richard Posner.

In some of his writings, Posner appears to justify using compulsion to achieve Kaldor-Hicks efficiency on the ground that, since we know nothing about the winners and the losers, the best assumption we can make about them is that they are the same. If this is true, then, at least on utilitarian grounds, anything that gives the winners more than it removes from the losers is an improvement. The problem with this approach, as I have pointed out before, is that we can assume that the winners and losers are the same only if we discuss the issue abstractly, calling the winners $A$ and the losers $B .^{34}$ The moment we deal with a real situation, we know something more about who wins and who loses. Once we are no longer ignorant, any number of differences may cause us to believe that losses or gains to some matter more than losses or gains to others. In other words, we are immediately in a real world where we must deal with competing theories of just distribution and in which a theory maintaining that losses and gains to everyone, rich and poor, good and bad, regardless of starting points, are of the same social significance, has little to commend it. ${ }^{35}$

33. Of course, some would argue that a measure of wealth-maximization, as opposed to utilitymaximization, requires no interpersonal utility comparison. See infra note 35 . This denial can only succeed, however, if wealth can be justified as a goal independent of utility. See J. CoLEMAN, supra note 19, at 111-21.

34. See Posner, The Ethical and Political Basis of the Efficiency Norm in Common Law Adjudication, 8 HOFSTRA L. REV. 487, 490-91 (1980); Calabresi, The New Economic Analysis of Law: Scholarship, Sophistry, or Self-Indulgence?, 68 PROC. BRTT. ACAD. 85, 90-91 (1982).

35. See Calabresi, supra note 34, at 93.

At times Posner seems to admit that winners and losers in a wealth-maximization system are not necessarily the same and suggests that since it is impossible to determine which individuals are morally worthy, the best that we can do is to maximize wealth. See Posner, A Reply to Some Recent Criticisms of the Efficiency Theory of the Common Law, 9 HOFSTRA L. REV. 775, 778 \& n.10 (1981). This occurs when winners and losers are treated as if they were the same. The problem remains, however; that maximization of wealth has no independent social value. It cannot be accepted as a good in itself, without support from 
Do not misunderstand me. I am not suggesting that we cannot say anything about just distribution. My position is quite the opposite, as I shall try to demonstrate at length in subsequent articles. Indeed, one conclusion of this Article will be that the failure of the Pareto criterion to be of any real guidance makes inevitable a thoroughgoing and open discussion of distribution and of interpersonal comparisons. Nor am I suggesting that Posner's distributional theory is always wrong. There may be situations in which winners and losers are random, or where the incidence of the change cannot be determined, so that we cannot know who the winners and losers are. Then treating winners and losers as the same may well be justified. There may also be situations in which a just distributional theory leads to the conclusion that we are indifferent between the actual winners and the actual losers, and hence that any KaldorHicks superior change is desirable. ${ }^{36}$ But without a real-world look at a partic-

some moral-distributional theory. See Dworkin, supra note 13, at 583; J. COLEMAN, supra note 19, at 112. Pushed by Dworkin, Posner makes a lame attempt at such a theory when he suggests that wealth-maximization is just because it rewards individuals who possess economically efficient traits such as traditional Calvinist virtues. Posner, supra note 26 , at 119-36.

36. A common attempt at deriving such a theory assumes that society's distributional goals can be best achieved through general taxes and welfare programs and that we should therefore be indifferent to the distributional effects of any other particular changes. Under these circumstances all Kaldor-Hicks superior moves, with or without compensation, are said to be justified. See, e.g., A.M. POLINSKY, AN INTRODUCTION TO LAW AND ECONOMICS 124-26 (2d ed. 1989).

There are, however, several problems with this approach. First, it assumes without argument that whoever sets general taxes and welfare programs is better suited to decide what is distributionally just than, say, judges, juries, or anyone else who decides particular cases, or than some combination of these. This is anything but obvious. The link between majoritarianism (even assuming that tax authorities are majoritarian) and just distribution is by no means clear. Valid philosophical notions of justice may have more impact, for example, on judges than on legislators. Moreover, individual particularized facts may be crucial to determining a just distribution. Indeed, reduced to the absurd, the argument would seem to suggest that rules of law that make the "wrongful" liable are not justified unless they can be shown to benefit the "rightful" winners more than they cost the "wrongful" losers. Proper distribution between "rightful" and "wrongful" - as between rich and poor-the argument implies, should be decided at a general tax, welfare level. In our system of checks and balances, however, it seems especially likely to be the case that the closest we can come to a just distribution, among rich and poor as well as among "rightful" and "wrongful," is through some generalized decisions by taxing authorities and some other rules of law, and even some case-by-case decisions (perhaps including highly particularized ones such as those made by juries) which favor certain groups or individuals.

One could, of course, argue that our desire to punish the wrongful is a consideration that should be taken into account in deciding whether holding the wrongful liable is Kaldor-Hicks superior. But then one could make exactly the same argument with respect to our desire to benefit, say, the poor. In either case, distributional considerations would, in practice, affect individual rather than general taxing decisions. (What is best treated as a matter of distribution and what is best treated as a matter of efficiency, in this sense, I must leave for a subsequent article.)

Second, the argument is often partly based on the assumption that redistribution achieved through taxation and welfare programs is more efficient (in a Kaldor-Hicks sense) than redistribution achieved through rules of law or through case-by-case decisions. Even if it were, this would not prove the point unless the distribution were also as "just." But, in fact, it is far from obvious that, as a general matter, tax and welfare programs are more efficient than a mixture of these and of other rules of law. Assume for the moment that a society wishes to redistribute wealth from the relatively rich to the relatively poor, or from the middle-aged to the elderly. It could do so at considerable expense through taxation and spending programs. But it could also do so to some extent by choosing a first-party system of automobile accident rules rather than a third-party system. If first-party systems are nearly as efficient in reducing the sum of accident and safety costs as are third-party systems, choosing a first-party system may be a Kaldor-Hicks superior way of achieving the desired redistributive effect, even if, apart from our distributional desires, 
ular situation, followed by the application of an explicit distributional theory to that situation, the attempt to make Kaldor-Hicks efficiency into a general normative guide must fail. It can be no more than a disingenuous attempt to convert a distributional theory of uncertain validity into one that has genuine distributional neutrality. ${ }^{37}$

Posner himself seems to acknowledge that Kaldor-Hicks superior moves have nonneutral distributional consequences. In some writings he attempts to justify coercive moves to Kaldor-Hicks efficient points by suggesting that in such cases one can assume ex ante consent to the coercion. He posits that, in some nonexistent social contract, we all agreed to go along with any changes that would yield a Kaldor-Hicks improvement. ${ }^{38}$ There are at least two problems with this. First, no such social contract was ever made. The fairness of the result must depend, therefore, not on unanimous consent but on the pseudocontract's inherent plausibility. Second, if there had been such a contract, it is far from clear that the parties to it would have agreed upon Kaldor-Hicks efficiency as the goal. In fact, Kaldor-Hicks efficiency is by no means the most plausible goal. In the absence of any actual agreement we will all have our own ideas of what a just social contract would look like. Some might indeed assume that Kaldor-Hicks would play a dominant role. ${ }^{39}$ But others might as readily put all sorts of other clauses into that nonagreement, leading to widely different distributional effects. John Rawls, for example, has made the most distinguished recent attempt to give some meaning to such nonexistent agreements. ${ }^{40}$ His notion of what we would agree to behind a veil of ignorance-the "maximin" concept-is very different from a simplistic compact to abide by whatever yields a Kaldor-Hicks improvement. ${ }^{41}$

Another, and rather different, problem with any attempt to convert KaldorHicks moves into voluntary, and hence Pareto, moves, by postulating an earlier unanimous agreement to accept compulsion, is that even if people did at an earlier time make such an agreement, they may now regret it. If this is so, any such move will yield losers. Once again it will be impossible to say that a social improvement has occurred without making interpersonal comparisons

third-party systems would be slightly Kaldor-Hicks superior. See, e.g., Calabresi, First Party, Third Party, and Product Liability Systems: Can Economic Analysis of Law Tell Us Anything About Them?, 69 IowA L. REV. 833 (1984).

I conclude that as a general defense of a Kaldor-Hicks test, this approach fails. This does not mean, of course, that in specific situations the possibility of redistribution through taxes and welfare rules will not justify the use of a Kaldor-Hicks test.

37. See Calabresi, supra note 36 , at $833-34$; Calabresi, supra note 34 , at 93.

38. Posner, supra note 34, at 491-96. James Buchanan has also tried to build arguments based on some similar notions of ex ante "agreements." J. BUCHANAN, EXPLORATIONS INTO CONSTITUTIONAL ECONOMICS 37-50 (1989); J. BuchanaN \& G. Tullock, The Calculus of Consent 12-15 (1962).

39. See, e.g., G. STIGLER, supra note 12, at 17; cf. Harsanyi, Morality and the Theory of Rational Behavior, 44 SOC. RES. 623, 631-47 (1977) (choices among moral codes must be determined according to total maximum utility).

40. J. RAWLS, A THEORY OF JUSTICE (1971).

41. Id. at 150-57. 
(deciding, for example, that those who change their minds should be ignored, that their hurt does not matter).

I treat this problem with Kaldor-Hicks moves separately because this problem can be said to apply to real Pareto moves as well. It casts doubt on the desirability of those changes upon which people truly agree unanimously and that occur without the need for compulsion or complex analysis. Here too, after all, some who agree to the change may later regret it. The problem of regret-of ex ante and ex post preferences-is a highly complicated one and is beyond the scope of this Article. It is an issue that I will need to discuss in a subsequent essay, in which I will analyze the theoretical symmetry between market and nonmarket approaches, between individualistic and collective decisionmaking. I will discuss it then because the problem of mistake and regret is equally crucial to both market and nonmarket approaches. ${ }^{42}$

For now, however, it is enough to say that even if one postulates no mistakes or regrets, or if one is willing to accept a distributional theory that ignores the losses of those who have erred or changed their minds, the attempt to make compelled moves to Kaldor-Hicks efficiency into true Pareto moves still must fail. It is one thing to say that we will ignore the hurt of those who have changed their mind. It is quite another to say that we will ignore the losses of those who never agreed to a change, because we believe that they should have ${ }^{43}$ And, in the end, that is what Posner's ex ante consent amounts to. As with Posner's distributional theory (that all winners and all losers are the same) I do not wish to rule out the possibility that his apparent moral theory (that Kaldor-Hicks efficiency is the desirable goal of a good society and that all should be bound to it) may be a valid one in some circumstances. ${ }^{44}$ But it will

42. Regret raises many issues that are worth in-depth discussion. One issue is the difference between regret due to a mistake or a change of mind and regret that is the outcome of something we would do again (for example, the regret we feel because we did not win the lottery in a situation where we will cheerfully enter the next lottery). Regret also raises the question of just end states versus just processes. Thus, if the process entered into by the party who now feels regret is deemed just, we may accept the end state as just, even if that same end state (with the same person experiencing regret) would be unjust were it reached by another process. Conversely, we may deem an end state unjust, even though all in it would admit to being better off, because the process by which it was reached was deemed unjust (if, for instance, it involved violent coercion of someone who now is glad he was coerced). The amount of time that has elapsed between a particular decision and the events that led the decisionmaker to regret that decision is often crucial both to process and to end-state justice in such regret situations. Thus, we may feel very differently about holding an old person to a decision made in youth than we do about holding someone to the financial consequences of a contract recently made. Finally, regret raises questions of what properly should be held static in efficiency tests and what, if any, dynamic elements can instead be introduced into such tests.

The complexity of our views of regret are best seen by considering the Faust legend. Faust made a clear choice. He subsequently regretted it. In many versions of the legend he goes to hell. In others he is saved, despite his choice and the good times it brought him. The longstanding appeal of the legend and its diverse endings in different versions suggest our deep ambivalence with regard to the underlying issue involved. See G. CALABRESI \& P. BOBBITT, supra note 11, at 121; Dworkin, supra note 13, at 574-79.

43. This distinction makes sense intuitively, and many would be willing to treat the two situations differently. Analytically, of course, both involve interpersonal comparisons and hence pose the same problems. For a discussion of the interpersonal utility comparisons problem, see Harsanyi, supra note 39, at 638-42; see also J. COLEMAN, supra note 19, at 104-05.

44. See Calabresi, supra note 34 , at 106-07. 
not suffice simply to assert that this is so. Too many other moral theories are at least as plausible.

Unlike true Pareto optimality which would, if it meant anything, have genuinely broad moral appeal despite the problem of regret, Kaldor-Hicks efficiency cannot have an equivalent appeal. And so we return to the problems and possibilities left to us in a world in which what is is Pareto optimal (until we change it), and in which the status quo may well be far from the best that we think can be done. It may be far from the best because we might want to make all sorts of changes if we were willing to make distributional judgments among winners and losers. It will also be far from the best if we are correct in believing that, with due effort, we can reduce both transaction costs and other barriers which keep us from improving everyone's lot; if, in other words, we can push the frontier outward through innovations in knowledge, organization, and science which could-at least in theory-make everyone better off.

I will spend a few moments on the first of these issues: the inevitability of distributional analysis. In the remainder of this Article I will focus on the second, and will make a few halting steps toward a new taxonomy of barriers-one more helpful than the Pareto terminology in indicating where our efforts toward betterment should be directed.

\section{The InEvitability of Distributional ANALYsis}

The failure of the Pareto test to give any practical guidance means that, in the absence of innovations which might allow all to be made better off, all alleged improvements entail, at least ex ante, the possibility of losers. Ex post, we might find that we were lucky, and that the losers now gloried in the change. But we could never be sure ahead of time, and so could never use that as a full justification for making the change. It follows that neither criticism of the status quo, nor support for it, can be distributionally neutral ${ }^{45}$ The great attempt to avoid interpersonal comparisons and to make economics what Lionel Robbins wished it to be-a science immune from distributional contaminants ${ }^{46}$ - must be recognized once and for all as a total failure.

Far from being a disaster, however, this fact should be a liberating force. It means that economists and lawyer-economists need not indulge in all sorts of contrary-to-fact assumptions to shore up the crumbling castle. They need no longer postulate that individuals always know best for themselves; ${ }^{47}$ nor need

45. The basic economic principle of opportunity cost means that even a choice to take no action has distributional consequences. See P. SAMUELSON, ECONOMICs 472-73 (9th ed. 1973); $c f$. infra note 73 (Dean Michael Levine makes point that investing in destruction of particular barriers precludes investment in overcoming other barriers, and so entails opportunity costs).

46. See L. ROBBINS, supra note 14.

47. Unless individuals always know what is best for themselves, free transactions will necessarily involve losers. The moment losers are a necessary part of the process, any statement that the result is superior entails a comparison between winners and losers, that is, an interpersonal comparison. Even if most 
they assume, as even an occasional silent premise of Kaldor-Hicks analysis, that winners and losers are all the same. Economists and lawyer-economists can now cheerfully accept even regret and changes of mind into their models. For if where we are is, for the moment, Pareto optimal and, absent innovations, all improvements must, ex ante, entail some losers, then we can also do away with these other "convenient" assumptions designed to negate the existence of losers. Distributional analysis becomes inevitable and hence essential, and economists must, at a minimum, become explicit about the distributional judgments (or guesses) that they are making. Decisionmakers can then accept or reject such judgments and guesses as they choose. But economists need no longer use terms in ways that, however unintentionally, can easily be misunderstood by decisionmakers as leading to conclusions that have normative validity independent of their distributional effects!

In fact, I believe that more can be done. ${ }^{48}$ For it seems to me that economists and lawyer-economists can have a great deal to say, as scholars, ${ }^{49}$ about what is distributionally desirable. We need not simply make our distributional judgments clear and let political decisionmakers accept them or not. We can develop scholarly definitions of just distributions, both theoretical definitions, ${ }^{50}$ and definitions based on empirical studies of particular societies. ${ }^{51}$ But a further discussion of such distributional studies, like the discussion of the parallelism between market and nonmarket decisions, must await subsequent articles. In this Article, I wish to focus on the question of replacing the misguided attempt to distinguish between efficiency moves and innovations, between moves to the Pareto frontier and shifts of that frontier.

individuals know what is best for themselves, the problem remains. For then one must compare the losses of the many who would lose as a result of being prohibited from transacting with the gains of those for whom freedom to transact is harmful. And that, again, involves an interpersonal comparison, unless the winners compensate the losers.

48. See Calabresi, supra note 36, at 847; Calabresi, supra note 34, at 103.

49. I have elsewhere criticized some of my own early writings because, though they were explicit about distributional preferences, they were not based on any special skills or analyses associated with scholarly work. I suggested that such personal distributional views, though perfectly appropriate for all of us-including scholars-in our role as citizens, are a self-indulgent crutch when presented in a scholarly work as part of that work's scholarship. See Calabresi, supra note 36 , at 848 n.40; Calabresi, supra note 34 , at $97-98$.

50. For examples of scholars who have developed theoretical definitions of just distributions, see J. BENTHAM, The Philosophy of Economic Science, in 1 JEREMY BENTHAM's ECONOMC WRTINGS 81 (W. Stark ed. 1952); J. COLEMAN, supra note 14; J. COLEMAN, supra note 19; A. LERNER, THE ECONOMICS OF CONTROL: PRINCIPLES OF WELFARE ECONOMICS 7-40 (1944); I. LITTLE, A CRITQUE OF WELFARE ECONOMICS (2d ed. 1957); Sen, Social Choice Theory: A Re-examination, 45 ECONOMETRICA 53 (1977); Sen, Utilitarianism and Welfarism, 76 J. PHIL. 463 (1979); Sen, The Welfare Basis of Real Income Comparisons: A Survey, 17 J. ECON. LITERATURE 1 (1979).

51. For examples of scholars who have developed empirical, society-based approaches, see M. WALZER, SPHERES OF JUSTICE (1983); Calabresi, supra note 36; Calabresi, Transaction Costs, supra note 9. 


\section{TOWARD A NEW TAXONOMY}

Most economists, if they stopped to think about it, would take for granted much of what I have said. They might not link it, as I have, to Coase's insight. But they might well say that they have always known that strict Pareto superiority was an unreal criterion..$^{52}$ Yet many persist in using the Pareto criterion as a crutch, as if its fundamental emptiness did not matter. ${ }^{53}$ And most of those who do not do this use the differently, but just as fundamentally, flawed Kaldor-Hicks test. ${ }^{54}$ Is this a harmless quirk of the profession or is it, in fact, something that hinders what economists and lawyer-economists should be doing?

Obviously, I believe that using Pareto as a crutch is positively harmful. I believe this not only because such use of Pareto tends to hide the inevitability of distributional issues, but also because I think that using the Pareto crutch tends to impede serious analysis of the process of innovation by which, sometimes, all are made better off, though often all are not.

As I have said, economists using the Pareto criterion distinguish between moves to the Pareto frontier and moves that shift that frontier outward. The first describes the kind of Pareto superior moves that I have argued do not exist ex ante. The second refers to technological or other innovations that make possible improvements in well-being which previously were not feasible: a better wheat,

52. Some have gone much further and have approached the issue in ways not too dissimilar from mine. For examples of scholars who reject simplistic Pareto analysis in favor of approaches directly considering issues such as distributional concerns, transaction costs, and frontier-moving innovations, see G. BRENNAN \& J. BUCHANAN, THE REASON OF RULES: CONSTTUUTIONAL POLITICAL ECONOMY 135-50 (1985); Becker, A Theory of Competition Among Pressure Groups for Political Influence, 98 Q.J. ECON. 371, 394-96 (1983); Dahlman, The Problem of Externality, 22 J.L. \& ECON. 141, 150-61 (1979); Demsetz, Information and Efficiency: Another Viewpoint, 12 J.L. \& ECON. 1, 19-20 (1969); Markovits, The Relationship Between the Allocative Efficiency. Contextual Moral Permissibility, and Overall Desirability of a Private Act or Government Policy, in SMMPOSIUM ON LAW AND ECONOMICs 23, $42-48$ (Centre D'Etudes Juridiques Europeennes, University of Geneva Law School, 1990). I have also addressed this issue in G. CALABRESI \& P. BOBBITT, supra note 11, at 83-87; Calabresi, On the General State of Law and Economics Research Today and its Current Problems and Prospects, in LAW AND ECONOMICs 9, 11-12 (G. Skogh ed. 1978).

53. See, e.g., J. DE V. GRAAFF, THEORETICAL WELFARE ECONOMICS 6 (1967) (acknowledging that noneconomic variables are influenced by economic variables, but concluding that "the only satisfactory solution is to assume" that "non-economic variables are exogenous"); A.M. POLINSKY, supra note 36, at 9-10 (recognizing that there may be conflicts between efficiency and equity, but concluding that "for purposes of discussing the legal system, a reasonable simplifying assumption is that income can be costlessly redistributed") (emphasis in original); Bator, The Simple Analytics of Welfare Maximization, 47 AM. ECON. REV. 22, 28 (1957) (designating single optimal point on infinite continuum of Pareto-efficient solutions requires social welfare function, but such function "intrinsically ascientific"); Markovits, The Causes and Policy Significance of Pareto Resource Misallocation: A Checklist for Micro-Econumic Policy Analysis, 28 STAN. L. REV. 1, 4-5 (1975) (stating that Pareto misallocation does not necessarily imply desirability of government intervention, but focusing exclusively on causes and policy implications of Pareto misallocation).

54. See, e.g., W. LANDES \& R. POSNER, THE ECONOMIC STRUCTURE OF TORT LAW 17 (1987); R. POSNER, supra note 8, at 12-14 \& passim; Epstein, Rent Control and the Theory of Efficient Regulation, 54 BROOKLYN L. REV. 741, 760-61 (1988); Fisher, Reconstructing the Fair Use Doctrine, 101 HARV. L. REV. 1659, 1699 \& n.194 (1988); Haddock, An Economic Analysis of the Brady Report: Public Interest, Special Interest, or Rent Extraction?, 74 CORNELL L. REV. 841, 847 (1989). 
cheap solar energy, superconductors, manna. What I have been saying is that all changes that we are concerned with are of one of two sorts. First, there are moves in which there are winners and losers, i.e., moves along the frontier. In such moves, winners may win more than losers lose, but compensation is not achievable. These moves can be justified only if one considers who the winners and losers are and what they have won or lost. ${ }^{55}$ This, of course, is the implicit basis of much of actual law and economic analysis. ${ }^{56}$ Second, and at least as important, are shifts of the frontier which create winners and may or may not create losers as well. These have been emphasized much less by economic analysis of law.

The interesting thing about shifts of the frontier is that economists and lawyer-economists tend to speak of those "technological" and knowledge innovations which are for them to discover and convince us of as if they were "merely" moves to the frontier, moves to Pareto optimality. ${ }^{57}$ Those technological and knowledge innovations that we pay other disciplines to make (and to sell us on), on the other hand, are described as shifts of the frontier, as outside the Pareto system..$^{58}$ This classification has, in my judgment, led to inadequate

55. There is, of course, another way to justify moves that entail winners and losers: that is, to look at whether the process by which the move is made or decided upon is just. The relationship between just end states and fair process is a complex one which, while it affects much of what I say, see, e.g., supra note 42 (discussion of regret), is beyond the scope of this Article.

56. For relatively explicit admissions that considerations about winners and losers justify the solutions offered by law and economics, see R. BORK, THE ANTITRUST PARADOX: A POLICY AT WAR WITH ITSELF $72-89$ (1978); W. LANDES \& R. POSNER, supra note 54, at 18; Posner, supra note 34, at 498-99. For examples of concurring views that law and economic analysis necessarily rests on assumptions about distributional consequences, see Baker, Starting Points in Economic Analysis of Law, 8 HoFSTRA L. REV. 939, 953 (1980); Baker, The Ideology of the Economic Analysis of Law, 5 Pun. \& PUB. AFF. 3, 9 (1975); Bebchuk, The Pursuit of a Bigger Pie: Can Everyone Expect A Bigger Slice?, 8 HofsTRA L. REv. 671, 677-84 (1980); Dworkin, supra note 13, at 584; Dworkin, Is Wealth a Value?, 9 J. LEGAL STUD. 191, 21219 (1980); Kronman, Wealth Maximization as a Normative Principle, 9 J. LEGAL STUD. 227, 240-42 (1980); White, Coase and the Courts: Economics for the Common Man, 72 IOWA L. REV. 577, 606-11 (1987); see also Calabresi, About Law and Economics: A Letter to Ronald Dworkin, 8 HOFSTRA L. REV. 553, 555 (1980); Calabresi, supra note 36, at 833-34; Calabresi, supra note 34, at 90-92.

57. Posner, for example, claims that judges and legal scholars ought to focus on efficiency-enhancing legal principles because efficiency is the only value courts can effectively promote. R. POSNER, supra note 8, at 23. For examples of similar statements by economists that economics primarily offers insights into efficiency enhancement, see R. DORFMAN, P. SAMUELSON \& R. SOLOW, LINEAR PROGRAMMING AND ECONOMIC ANALYSIS 409 (1958) (Pareto optimum is "standard tool" of welfare economics for determining preferable social welfare options); R. MCKEAN, EFFIENCY IN GOVERNMENT THROUGH SYSTEMS ANALYSIS 132-33 (1958) (proposing cost-benefit analysis focusing on enhancing efficiency of government programs); E. MISHAN, ECONOMICS FOR SOCIAL DECISION 15 (1973) (all calculations in social welfare cost-benefit analysis "to be interpreted as contributions ... to the magnitude of some resulting potential Pareto improvement"); Diamond \& Mirrlees, On the Assignment of Liability: The Uniform Case, 6 BELL J. ECON. 487, 487 (1975) (offering economic analysis of more efficient allocation of externality costs); McKean, The Use of Shadow Prices, in Cost-BENEFIT ANALYSIS 119, 122-24 (R. Layard ed. 1972) (assuming as basis for analysis that government seeks Pareto optimality based on current wealth distribution); Stiglitz, Pareto Efficient and Optimal Taxation and the New New Welfare Economics, in 2 HANDBOOK OF PUBLIC ECONOMICS 991,992 (A. Auerbach \& M. Feldstein eds. 1987) (new welfare economics limited itself to identifying Pareto inefficiencies that could be eliminated).

58. For discussions of technological and knowledge innovations going beyond mere efficiency optimization, see, e.g., S. KUZNETS, SIX LECTURES ON ECONOMIC GROWTH 14-15 (1959) (marked increases in product per labor unit usually possible only through major innovations, including applications of scientific 
analysis of how we try to push the frontier outward. There are of course differences between what economists do and what engineers do. But there are also similarities. And there are great differences between what engineers, chemists, pharmacologists, and poets do. Any taxonomy that puts economists in one class and all other innovators in another must be prima facie suspect, both because of the differences it glosses over and because of the similarities it ignores. ${ }^{59}$

Instead, we should accept that we are always at the Pareto frontier, and that therefore all changes are, at the time we make them, either for someone's benefit and someone else's loss, or shifts of the frontier (resulting from innovations in what we know, believe, or can organize), or both. We would, then, likely come up with a more helpful classification than one that treats economic innovations as within the system and all other innovations as outside of it. For this traditional way of looking at innovations not only makes an arbitrary distinction among innovations, it may also mislead some into believing that what it describes as moves to the frontier are more easily achieved than shifts of the frontier. And that has no basis in fact. ${ }^{60}$ Freed from the fantasy of a set of "nonexistent" perfect improvements that are available under current knowledge, we might look to other, more meaningful ways to categorize innovations.

We might first try to identify those innovations-whether technological, knowledge-based, legal-institutional, or other-that might, conceivably, make it possible for everyone to be better off. We might concentrate, first, on finding those changes that do not immediately create new winners and uncompensated losers, distinguishing them from those changes in which the shift of the frontier itself creates conditions that make subsequent compensation costly or otherwise unlikely. We might then focus on whether there are ways of keeping the frontier from moving too quickly to hardened situations in which there are new gainers who will not compensate new losers; for example, we might consider

knowledge); Harberger, The Fundamentals of Economic Progress in Underdeveloped Countries: Using the Resources at Hand More Effectively, 49 AM. ECON. REV. 134, 134 (Supp. 1959) (spectacular advances in growth rate in developing countries will come from improvements in labor force and technical advances, not efficiency optimization).

To be sure, however, there are some areas of economics, such as development economics, which frequently and explicitly concern themselves with shifts of the frontier. See, e.g., N. BUCHANAN \& H. ELLIS, APPROACHES TO ECONOMIC DEVELOPMENT 406 (1955) (technical change, capital accumulation, entrepreneurship, and specialization and exchange most important sources of growth); E. HAGEN, THE ECONOMICS OF DEVELOPMENT 29 (1968) (capital formation and technical progress only important causes of economic development); G. MEIER \& R. BALDWIN, ECONOMIC DEVELOPMENT: THEORY, HISTORY, POLICX 336 (1957) ('major requirement is to push the production frontier outwards rather than merely reach a given production frontier"); J. RAFFAELE, THE ECONOMIC DEVELOPMENT OF NATIONS 360-67 (1971) (discussing need to shift flow of production inputs, including education, institutions, technology, environment, and motivation, to encourage economic growth).

59. To return to Coase, the traditional classification is similar to, and as misleading as, the failure to examine critically the costs that make firms more economical than markets and vice versa. Indeed, analytically the two may reflect exactly the same error.

60. I do not mean to suggest that serious economists are likely to be misled into thinking this task is easy. But the economists' "groupies"-popularizers, and even politicians who think they understand economics-may well be misled. 
what kinds of innovations can be linked ex ante to a compensation requirement that could itself be made part of the process of change. ${ }^{61}$

Secondly, we might try to focus on those changes (whether they involve a shift of the frontier or not, i.e., whether they are based on new knowledge or not) which inevitably make some people better off and some worse off. We would then center our attention on deciding which among these are likely to be worthwhile and which are not. The availability of Kaldor-Hicks improvements would certainly be one factor, but it would not be the only issue in the decision. The identity of the winners and losers would be at least as crucial. ${ }^{62}$

It is worth noting that most technological changes, like most legal ones, do entail both ultimate winners and uncompensated losers. Thus, despite our best efforts, most shifts of the frontier usually entail major moves along the frontier as well. The invention of the steam engine-which Justice Frankfurter called the most significant legal event of the nineteenth century ${ }^{63}$-led to all sorts of accident victims. Manna flowing from heaven would undoubtedly hurt the farmer's ability to sell her produce. And it is by no means clear that compensation, even if theoretically possible, ${ }^{64}$ would come about.

Thus, the object of at least one possible taxonomy of innovations would be to distinguish those shifts of the frontier that, if achieved, would permit compensation relatively easily, from those that would allow it, but only with difficulty. Both of these could then be distinguished from those changes that, even as a theoretical matter, cannot lead to full compensation.

Other classifications would be perhaps even more important. We could try to catalogue the types of barriers that keep us from moving the frontier outward (either for everyone's benefit, or for the benefit of those whom we wish to benefit). We might, for instance, focus on whether such barriers exist due to:

(a) technological incapacity (e.g., that which keeps us from developing a long-distance, battery-driven car);

(b) organizational incapacity (i.e., the failure to develop an adequate and acceptable way, in nonmarket situations, of causing preferences to

61. Even these are likely to entail losers: it seems improbable that any compensation requirement could reach everyone. In addition, unless the money to identify these innovations is given voluntarily, the strict Pareto conditions will be violated. Finally, such ex ante compensation requirements might well create a conservative bias that would block other improvements that could significantly benefit "worthy" gainers, with relatively small harms to losers about whom the society is not much concerned. These opportunity costs would, themselves, keep such compensation-linked innovations from leading to a state in which everyone was truly better off. $C f$. infra note 73 (Dean Michael Levine's statement that investment in the destruction of certain barriers precludes investment in overcoming other barriers, and thus entails opportunity costs).

62. See supra note 36.

63. In conversation with law clerks of various Justices, including the author, during the $1958 \mathrm{Term}$ of the Supreme Court of the United States.

64. Often it is not: Can you compensate fully someone who has been killed? Can you make up, in money, for the loss of a way of life? 
be revealed, ${ }^{65}$ leading, for example, to "large number" problems in economics, ${ }^{66}$ and to many of the difficulties associated with compensation in tort law ${ }^{67}$;

(c) knowledge incapacity (this is obviously related to technological incapacity, but what I mean by it is something like the inability to prove a theorem demonstrating that a move to state $B$ could make everyone better off than in condition $A$ );

(d) rhetorical or informational incapacity, or inability to convince people of their own interests (e.g., the difficulties, remarked on by economists, of trying to convince people that keeping money in a sock is not the most beneficial way to store it, or that a required minimum wage may hurt some of its strongest supporters). ${ }^{68}$ Even if knowledge

65. See Tideman \& Tullock, A New and Superior Process for Making Social Choices, 84 J. POL. EcoN. $1145,1145-46$ (1976) (identifying the problem of strategic maneuvering and proposing "demand-revealing solution"); see also Levmore, Self-assessed Valuation Systems for Tort and Other Law, 68 VA. L. REV. 771, $779,784,810-11,853$ (1982) (proposing market penalties, competitive bidding, first-party insurance coverage, and pre-tender offer bidding as solutions to problem of ensuring truthful preference revelation in property tax, tort liability, and self-assessment systems); Tideman, Ethical Foundations of the Demand Revealing Process, 29-2 PUBLIC CHOICE 71, 72-76 (1977) (developing statistically-based demand-revealing method for public decisionmaking).

66. The problem of large numbers involves the fact that "rational, self-interested individuals will not [in such circumstances] act to achieve their common or group interests" in the absence of coercion or some other incentive distinct from the group interest. M. OLSON, THE LOGIC OF COLLECTIVE ACTION: PUBLIC GOODS AND THE THEORY OF GROUPS 2 (1965). Large number problems arise where "no single individual's contribution makes a perceptible difference to the group as a whole, or [to] the burden or benefit of any single member of the group," or where "one member can decide whether or not the group would get a collective good." Id. at $44-45 \&$ n.66.

For discussions of the "large number" problem arising in the provision of public goods, regulation of externalities, and resolution of prisoner's dilemma situations, see J. CONYBEARE, TRADE WARS: THE THEORY AND PRACTICE OF INTERNATIONAL COMMERCIAL RIVALRY 56-62, 233-61 (1987); D. MUELLER, PUBLIC CHOICE 13-15, 34-35 (1979); M. OLson, supra, at 9-16, 43-52; Cornes \& Sandler, Easy Riders, Joint Production, and Public Goods, 94 ECON. J. 580, 589 (1984). For a discussion of how large-group decisionmaking increases opportunities for strategic behavior and the cost of decisionmaking, see J. BUCHANAN \& G. TULLOCK, supra note 38 , at 105-06.

67. For discussions of the difficulties in accurately measuring idiosyncratic valuations of injuries, and the problems these difficulties pose for determining compensation for torts, see G. CALABRESI, THE CosTs OF ACCIDENTS: A LEGAL AND ECONOMIC ANALYSIS 205-25 (1970); Borvberg, Sloan \& Blumstein, Valuing Life and Limb in Tort: Scheduling 'Pain and Suffering,' 83 Nw. U.L. REV. 908, 952-53 (1989); Calabresi \& Melamed, supra note 10, at 1106-10; Ellickson, Alternatives to Zoning: Covenants, Nuisance Rules, and Fines as Land Use Controls, 40 U. CHI. L. REV. 681, 745-46 (1973); Ingber, Rethinking Intangible Injuries: A Focus on Remedy, 73 CALIF. L. REV. 772, 772-73 (1985); Levmore, supra note 65, at 790-837; Lewin, Compensated Injunctions and the Evolution of Nuisance Law, 71 IOWA L. REV. 775, 803-16 (1986); Smith, The Critics and the "Crisis": A Reassessment of Current Conceptions of Tort Law, 72 CORNELL L. REV. 765, 769-72 (1987).

Comparable issues arise in ascertaining and fairly compensating idiosyncratic and subjective valuations of property in the context of eminent domain. See, e.g., R. EPSTEIN, TAKINGS: PRIVATE PROPERTY AND THE POWER OF EMINENT DOMAIN, 182-86, 216-18 (1985); Knetsch \& Borcherding, Expropriation of Private Property and the Basis for Compensation, 29 U. TORONTO L.J. 237, 237-42 (1979); Merrill, The Economics of Public Use, 72 CORNELL L. REV. 61, 82-85 (1986).

68. See P. JOHNSON, SAVING AND SPENDING: THE WORKING-CLASS ECONOMY IN BRTTAIN 1870-1939, at 88, 97-98 (1985) (discussing working-class hoarding of savings and difficulties experienced by unskilled workers in discerning which forms of saving provide better value).

For evidence of the economic effects of minimum wage laws and consideration of the adverse impact of minimum wages on the young, the poor, and members of minority groups, see R. POSNER, supra note 
or technological incapacity were overcome, rhetorical incapacity might remain. Thus proving the theorem demonstrating that a move to state $B$ would be desirable does not guarantee that people will accept the proof. Similarly, if a long-distance, battery-driven car has been developed, it does not follow that people will in fact believe that it works. ${ }^{69}$

My list here is simplistic and rudimentary in the extreme. The process of usefully classifying "barriers" or "costs" is a hard one, even when we realize what we ought to be doing. ${ }^{70}$ It is at the core of Professor Oliver Williamson's highly innovative work on transaction cost economics. ${ }^{71}$ Here again the link to Coase becomes apparent. For Williamson's work involves the classification and analysis of precisely those barriers to moving the frontier outward that Coase termed transaction costs. ${ }^{72}$ The failure of the Pareto test elaborated in

8, at 308-10; Behrman, Sickles \& Taubman, The Impact of Minimum Wages on the Distributions of Earnings for Major Race-Sex Groups: A Dynamic Analysis, 73 AM. ECON. REV. 766 (1983); Brown, Gilroy \& Kohen, The Effect of the Minimum Wage on Employment and Unemployment, 20 J. ECON. LTT. 487 (1982); Linnemann, The Economic Impacts of Minimum Wage Laws: A New Look at an Old Question, $90 \mathrm{~J}$. POL. ECON. 443 (1982); Mincer, Unemployment Effects of Minimum Wages, 84 J. POL. ECON. S87 (1976). For a discussion of rhetorical incapacity in convincing individuals of their insurance needs, see G. CALABRESI, supra note 67 , at $56-57$.

69. Rhetorical incapacity may also include the difficulties entailed in educating people as to what their entitlements are.

70. Jules Coleman has suggested to me a more complex taxonomy which would distinguish among: (a) the costs of disposing oneself to act in certain ways that make possible cooperative gains that would not be available otherwise; (b) the costs of disposing oneself to act in compliant or cooperative ways when the rationality of doing so depends on the existence of others being similarly disposed and one does not know whether or not they are (the key in both of these cases is the possibility of revising one's dispositions, as opposed to the costs of external coercive machinery); and (c) the costs of changing the rules or structure of the game or the institutional framework so as to make possible gains that are unavailable when the game is the one we are currently playing. Bruce Ackerman would favor taxonomies that distinguish between ways of evaluating transitions and ways of evaluating end states. Robert Ellickson, in a recent Yale Law Journal article, suggests a taxonomy of transaction costs that would divide them into: (a) get-together costs; (b) decision and execution costs; and (c) information costs (he then proceeds to make further distinctions within these, especially with respect to information costs.). See Ellickson, supra note 20.

All of these have considerable merit. My object, however, is not to come up with a definitive or even a somewhat finished taxonomy. It is rather to suggest some of the things that we ought to be thinking about in developing a taxonomy once we have come to realize that the currently dominant one does not work.

71. See, e.g., O. WILLIAMSON, MARKETS AND HIERARCHIES: ANALYSIS AND ANTITRUST IMPLICATIONS (1975); Williamson, Transaction Cost Economics, in HANDBOOK OF INDUSTRIAL ORGANIZATION (R. Schmalensee \& R. Willig eds. 1989); Williamson, Transaction-Cost Economics: The Governance of Contractual Relations, 22 J.L. \& ECON. 3 (1979) [hereinafter Williamson, Governance]; Williamson, $A$ Microanalytic Assessment of "The Share Economy," 95 YALE L.J. 627 (1986). For appreciations of the significance of Williamson's work, see Hart, Incomplete Contracts and the Theory of the Firm, 4 J.L. ECON. \& ORG. 119, 121-24 (1988); Joskow, Asset Specificity and the Structure of Vertical Relationships: Empirical Evidence, 4 J.L. ECON. \& ORG. 95, 97-102 (1988).

72. For examples of classification and analysis of transaction costs, see $O$. WILliamson, THE ECONOMIC INSTITUTIONS OF CAPITALISM 43-63 (1985) (lock-in effects); O. WILLIAMSON, supra note 71, at 20-40 \& passim (1975) (discussing "bounded rationality," "opportunism," "small-numbers bargaining," and "information impactedness"); Williamson, Credible Commitments: Using Hostages to Support Exchange, 73 AM. ECON. REV. 519 (1983) (human asset, physical asset, and site specificity); Williamson, Franchise Bidding for Natural Monopolies_In General and with Regard to CATV, 7 BELL J. ECON. 73 (1976) (asset specificity); Williamson, Governance, supra note 71 (idiosyncratic investments); Goldberg, Regulation and Administered Contracts, 7 BELL J. ECON. 426 (1976) (link between relationship-specific investments and opportunistic behavior); Grossman \& Hart, The Costs and Benefits of Ownership: A Theory of Vertical Integration, 94 J. POL. ECON. 691 (1986) (difficulty in particularizing extensive contractual rights); Hart, 
this Article means that we are bound to engage in Williamsonian analysis, possibly on an even broader scale than Williamson himself.

Once we have appropriately categorized barriers to innovation we can then decide which are worth attacking and which are not. This involves guessing or analyzing which of these barriers we can most likely eliminate at the least social cost if, for example, we invest in research on how to destroy them. Barriers might be worth battering because they are likely to fall fairly easily and because, if they fall, everyone would be better off. But barriers might also be appropriate targets (perhaps even better targets) because we have reason to believe that the cost of attacking them would not be too high, and that a sufficient number of worthy gainers would benefit at relatively little cost to the losers. ${ }^{73}$

This kind of analysis also suggests that we inquire into which categories of inventors-innovators are most worth supporting. It would require us to consider whether, at any given time, we can expect the greatest payoffs from economists, lawyer-economists, physicists, engineers, psychologists, or poets. ${ }^{74}$ Which of these are best suited to identify the gambles that are "relatively" worthwhile? Which are most suited to pull the gamble off? All this may sound frightfully materialistic. But, if it does, the reader has forgotten that shifts of the frontier are not, by any means, only material. They can be moral, aesthetic, and altruistic as well. ${ }^{75}$ Once again, analytical failures may have led to an inordinate focus on economists and lawyer-economists and their agendas (because what they foster are "simply moves to the frontier") and on hard scientists (because, in contradistinction to economists, they really shift the

supra note 71 (strategic behavior "creaming off" profits); Joskow, supra note 71 (relationship-specific investments, information asymmetry, costs of writing, monitoring, and enforcing contracts, asset specificity); Klein, Crawford \& Alchian, Vertical Integration, Appropriable Rents, and the Competitive Contracting Process, 21 J.L. \& ECON. 297 (1978) (relationship-specific investments).

73. Where investments in research are not voluntarily made, the destruction of barriers whose removal would improve everyone's lot entails ex ante losers: those compelled to invest. Even voluntary investments, however, entail losers, if making them precludes other investments that would have destroyed other barriers. For those who could more greatly benefit from the destruction of these other barriers suffer the opportunity costs of the original investments. Dean Michael Levine made this point as a comment to this paper at the Coase conference described above, supra note 1 .

74. Alternatively, it might indicate the desirability of creating structures that would take these payoffs into account in determining funding, without requiring explicit collective consideration of what categories have the greatest payoff potential. Again, market and nonmarket approaches to the solution are quite symmetrical.

75. The word "frontier" with its implication of materiality and even of units of measurement makes forgetting this all too easy. One should, however, try to remember that words like "frontier" or "costs" are used for convenience in such discussions and need not entail the materiality they suggest.

For a suggestion of how changes in morality and altruistic behavior might move the Pareto frontier outward, see A. BUCHANAN, MARX AND JUSTICE: THE RADICAL CRTIQUE OF LIBERALISM 92-97 (1982) ("in-process" benefits, but not coercion or moral principles, can overcome public goods problems in manner compatible with Marxist principles); D. GAUTHIER, MORALS BY AGREEMENT 4, 113 (1986) (moral principles derived from rational choice theory can provide social benefits through enhanced cooperation); M. TAYLOR, COMMUNTTY, ANARCHY AND LIBERTY 59 (1982) (communitarian anarchism as means for providing public goods); M. TAYLOR, THE POSSIBILITY OF COOPERATION 30 (1987) (discussing voluntary cooperation as solution to problems of collective action, such as provision of public goods). 
frontier).$^{76}$ Other disciplines which might, when they shift the frontier, do so with few losers, or at little cost, may have been left out of the picture. ${ }^{77}$

I do not mean to suggest that economics or hard science is not as worthy of support as comparative literature, or perhaps even more so. I mean only to criticize a model which, at least psychologically, if not necessarily logically, makes it hard to pay real attention to the problem of determining which barriers to a better life are worth attacking and which are not. The neutral economics of Pareto and Lionel Robbins lead us to focus on those situations in which improvements would occur only if certain hypothetical conditions hold true: "if there were no externalities or transaction costs"; "if only people were less pig-headed and accepted what economists demonstrated"; or, "if only a different organizational or legal structure - that is not in fact available-existed." In other words, "if only the world were different from what it is." So long as we focus on these situations, however, we are likely to miss other excellent opportunities for bettering our lives. Sometimes these improvements premised on "if only" will actually present the most promising ways of moving the frontier outward. But at other times they will be totally fanciful and their achievement impossible or extremely costly. We will not, however, get very far in deciding whether they are easy or impossible if they are all treated as similar, as moves to the frontier in a simplistic Pareto optimality model.

Taking seriously Coase's insight that everything, including existing markets and potential markets, has costs, means that we can concentrate on which kinds of costs we should realistically try to reduce and which we should not, for the moment, bother with. This is the kind of analysis that Williamsonian transaction cost economics has attempted, with considerable success, within economics. ${ }^{78}$

76. For examples of the focus on the agendas of lawyer-economists, see supra notes 57-60 and accompanying text. It is a commonplace of one genre of academic economic literature that innovations in science and technology make the most significant contribution to the material well-being of society. See, e.g., J. KENDRICK, PRODUCTIVITY TRENDS IN THE UNITED STATES 187 (1961) (innovation, scale, and business cycles major factors influencing productivity); S. KUZNETS, supra note 58, at 29 ("Continuous technological progress and, underlying it, a series of new scientific discoveries are the necessary conditions for the high rate of modern growth in per capita income combined with a substantial rate of growth in population."); Harberger, supra note 58, at 134 ("spectacular advances in the growth rate" come from increased pace of technical advance, not eliminating distortions in price mechanism).

77. I emphasize "few losers" or "at little cost" because poetry can harm too; it also has its costs. The costs discussed above, see supra note 73, apply to literature as well. There may also be other costs. Cf. D. ALIGHIERI, INFERNO canto V (A. Mandelbaum trans. 1980) (literature incites activities resulting in eternal damnation:

One day, to pass the time away, we read / of Lancelot-how love had overcome him. / We were alone, and we suspected nothing. / And time and time again that reading led / our eyes to meet, and made our faces pale, / and yet one point alone defeated us. / When we had read how the desired smile / was kissed by one who was so true a lover, / this one, who never shall be parted from me, / while all his body trembled, kissed my mouth. / . . that day we read no more).

78. See, e.g., O. WILLIAMSON, supra note 71, at 115-16, 163-71, 223-26, 245-47, 258-63 (1975); Williamson, Assessing Vertical Market Restrictions: Antitrust Ramifications of the Transaction Cost Approach, 127 U. PA. L. REV. 953 (1979); Williamson, Intellectual Foundations: The Need for a Broader View, 33 J. LEgAL EDUC. 210 (1983); P. JOSKOW \& R. SCHMALENSEE, MARKETS FOR POWER: AN ANALYSIS OF ELECTRIC UTILITY DEREGULATION 129-52 (1983); Joskow, Price Adjustment in Long-term Contracts: The Case of Coal, 31 J.L. \& ECON. 47 (1988); Masten \& Crocker, Efficient Adaptation in Long-term 
Carrying Coase's insight further, to the denial of any difference between moves to the Pareto frontier and shifts of that frontier, leads to a broader, society-wide, analysis of the same sort. It requires us to ask of all human endeavors, including economics, that penultimate question: Which actions are most likely, at least cost, to shift the frontier outward, and who will gain and who will lose from such moves? ${ }^{79}$ Supplier Switching Costs and Vertical Integration in the Automobile Industry, 13 BELL J. ECON. 206 (1982).

79. Although this question is intimately linked to justice, for some of us, at least, it cannot be the ultimate one; that question must be transcendental. 
HeinOnline -- 100 Yale L.J. 1238 1990-1991 